\title{
Iranian Students' Recognition of Derived Nouns: Do Students Deal with Words as Entire Units Directly or through a Process of Word Building Strategy?
}

\author{
Mitra Amiri \\ Islamic Azad University of Njafabad Branh, Isfahan, Iran \\ Email: mitraamiri11@yahoo.com \\ Akbar Hesabi \\ University of Isfahn, Iran \\ Email: a.hesbi11@yahoo.com \\ Abbass Eslami Rasekh \\ University of Isfahn, Iran \\ Email:rasekh@yahoo.com
}

\begin{abstract}
The study presented in this article deals with the use of word-building strategy, one which helps EFL students' skill of word recognition. There are two observable strategies which are usually employed in working out the meaning of unknown words: The direct method refers to students' general attempt to learn vocabulary items without any conscious attention to the internal structure of the word. The second which is a word building process relies on the ability to work out the meaning of the item by analyzing the constituent parts of the word. The effect of each strategy could by subject to controversy. Is it the word building processes which might be used as a major strategy or is it dealing with words as entire units without attending to the parts? Thirty under-graduate students majoring in TEFL at Islamic Azad University, Najafabad Branch, participated in a task involving them in finding translation equivalents of lexical items presented to them in two translation tasks which required them to give the Persian (L1) translations for English words (L2). The words given to them in the tow tasks included both stem words as well as derived words. An Interview was run to get information about how the participants recognized the meaning of the words which were given to them to translate. The results of our comparison of the data showed that few students out of the entire population seemed to have and employ word-building knowledge. The majority did not use word-building knowledge in recognizing derived words; they favored an approach which involved attention to the whole unit. Students' word recognition was the found to be the consequence of frequency of exposure rather than knowledge of parts. Explanations are introduced for why EFL participants prefer to expand their vocabulary knowledge without much relying on derivations information available to them.
\end{abstract}

Index Terms — word-building strategy, word recognition, derived words

\section{INTRODUCTION}

Studying another language entails having a good knowledge of vocabulary which is crucial for second/foreign language (L2) students, and its mastery is considered an indispensable tool of L2 learning. Wilkins (1972) states that, "Without grammar, very little can be conveyed, without vocabulary nothing can be conveyed" (p.150).

Many linguists, then, endeavored to established a frame in order to explain what knowledge language learners should have for knowing a word completely, both receptively and productively (e.g., Richards, 1976; Nation, 1990, 2001). Vocabulary knowledge includes many components among which the spoken form, the written form, the grammatical behavior, and the collocational behavior of a word; how frequent the word is, the stylistic register constraints of a word, the conceptual meaning of a word, and the association of word with other related words can be named as the most important ones. Carter (1998) noted that word knowledge means "knowing how to use it productively and having the ability to recall it for active use" (p.239). This study searched one dimension, the knowledge of derivational morphology, which is a part of grammatical knowledge.

One of the important sources of learning for student at university is written texts (Mori \& Nagy, 1999). It is vital for the students to be capable to read English texts-especially academic texts. Thus, Iranian university students should know as much academic vocabulary as possible in order to assist them in reading academic texts. 
The Report of the National Reading Panel (2000), for example, concluded, "The importance of vocabulary knowledge has long been recognized in the development of reading skills. As early as 1924, researchers noted that growth in reading power relies on continuous growth in word knowledge" (p. 4).

Problems could happen when students decide to read a text with low vocabulary knowledge. As stated by Levine and Reves (1998) "lack of adequate vocabulary is one of the obstacles to text comprehension" (p. 302). Although many learning strategies, such as rote memorization, mnemonic devices, key word technique, inferring meaning from glosses, and guessing meaning from context, are introduced in order to help L2 students acquire words, L2 students still have reading problems when encountering texts outside the class. Motivating students to infer or find the meaning of the unknown words from the text without direct instruction is a remedy in overcoming the problems of comprehending a text outside the classroom.

As it was mentioned, one of the effective strategies to deal with unknown words in reading is to guess the meaning from the context. Students use the information in the context to guess the meaning of the unknown words in order to comprehend the L2 texts. However, there are some weak points concerning this method as a vocabulary learning strategy. Nation $(2001,2005)$ mentions several weak points of supposing from context as follows: it is based on the idea of incidental learning; that is, students are supposed to learn new words through an attempt to comprehend the text, not to learn and define only the unknown word. Nation (2001) hesitates that incidental learning is a useful way to acquire vocabulary.

Another problem in this domain is that the students need clues-namely linguistic clues such as the part of speech of word and the conjunction relationships and background knowledge clues. On the other hand, inferring the meaning of an unknown word from its word parts, which was under inquiry in this study, does not have to depend so much on the understanding of the context.

This study focused on the strategy of using word parts to infer the meaning of a whole word. In this study the researchers call this strategy as "word building". The impact of word parts and word families is often discussed at the same time. Bauer and Notion (1993) believe learners require less effort in learning new words that include parts which the learners are familiar with and then they can guess the meaning.

The knowledge of word parts and word families may have two positive influences: one is for remembering words, and the other is for inferring the meaning of words in their reading. As to the first influence, according to Nation (2001, 2005), students can learn unknown words if they recognize the word parts then make use of each part to understand the meaning of the whole.

\section{LITERATURE REVIEW}

Students usually use word-building strategy when they recognize the words (in case the new word consists of stem, which is a free or bound form, and affixes, which are prefixes and/or suffixes). Then, the students use the information from the headword (stem) and affix (es) to infer the meaning of the whole word (relate the meaning of each word part in order to infer the meaning of the whole word). The knowledge of word parts is claimed to make easy the recognition of the words with the same stem (Schmitt, 2000; Schmitt \& Zimmerman, 2002). Schmitt and McCarthy (1997, p. 277) mention that knowing of how words are made up "can help students to have at least a receptive knowledge" of the words in the same family. Nattinger (1988, p. 69) states that the impact of word parts is such that: "many words built about a particular root are gathered so that the associations among them can be seen. Even though the meanings of these words maybe slightly different, clustering them will aid students in remembering their general meaning". Inferring meaning from word parts, therefore, becomes a strategy for vocabulary learning since it makes learning more successful and decreases the difficulty in vocabulary learning.

Moreover, word-building strategy has an impact on students' reading. The ability to recognize the meaning after seeing the word parts facilitates reading comprehension (Richard \& Schmidt, 2002). Paribakht (2004) mentions that L2 students use the grammatical knowledge of inflections and derivations to attack the unknown L2 words in their reading. Schmitt and Meara's (1997) study showed the results that their participants' suffix knowledge was poor. They were Japanese students whose major English. As a group, the participants showed 62-66\% achievement (with 57\% mastery of inflection on the receptive section); on the productive section, they mastered $59 \%$ of inflection and $15 \%$ of derivation. The top four verbal suffixes given to the participants were three inflections (-ed, -ing and -s) and a derivation (-ment). Schmitt and Meara (1997) explained that the difference between the inflection and derivation scores was because inflections are more rule-based (for example, students know that inflectional suffixes in the tests can be added to verbs). On the contrary, derivations in the study needed idiosyncratic knowledge (Schmitt \& Zimmerman, 2002). This means students need to memorize L2 derived words because there is no principal way to recognize or recall the tested word from its word parts. In this case, the students could not make much use of the patterns of word formation. The study by Schmitt and Zimmerman's (2002) researched the suffix knowledge with different word classes such as nouns, verbs, adjectives, and adverbs.

The results showed that students could produce around 37.6 words out of maximum possible of 64 words or around $58.8 \%$. That was from the four word classes used in the study-nouns, verbs, adjectives, and adverbs-students produced only two word classes. The two word classes were nouns and verbs. While students as a group produced appropriate noun and verb forms of the headword, they could not produce appropriate forms for adjective and adverb. If the word 
family was being used here, then students should be able to make use of word parts and produced all word classes. However, the results were against the idea that knowing one word in a family helps students to know other words in the same family. The researchers assumed that knowing some words in a family did not "imply productive knowledge of all (or even most) of the other word forms" (Schmitt \& Zimmerman, 2002, p. 158).

\section{OBJECTIVE OF THE STUDY: WORD-BUILDING}

The purpose of the present study was to investigate Iranian learners' knowledge regarding word-building. By wordbuilding it means using morphological analysis of words for the purpose of learning, understanding, or remembering what they mean- what Nation (2001, p. 278) refers to as the "word part strategy for learning complex new words".

\section{RESEARCH QUESTION}

The following question was raised in this study:

Do Iranian students recognize derived nouns directly or through a process of word-building?

\section{RESEARCH HYPOTHESIS}

The present study tried to investigate the following null hypothesis.

Ho: There is no difference between the direct and word-building strategies of derived nouns recognition by Iranian students.

\section{SIGNIFICANCE OF THE STUDY}

Many high school and university textbooks have exercises based on the idea that word-building is a practical and useful strategy for high school and university students. Thus, exploring the current status of whether Iranian students recognize derived nouns directly or through a process of word-building helps English teachers understand whether or not word part strategy plays a role in students' recognition of second language vocabulary. The knowledge of suffixes also relates to the students' reading skill since it helps students expand their vocabulary. Moreover, this study helps English teachers in making decisions about vocabulary presentation, practice, and testing. This research will help other researchers who are interested in analyzing affixation.

\section{METHOdOLOGY}

\section{A. Participants}

At the first attempt, the participants of this study, who were selected randomly, were 40 male and female, undergraduate students, majoring in English teaching, studying at Islamic Azad University, Najafabad Branch, Esfahan, Iran. The researchers excluded 10 students who just took part in one test, so the information finally came from 30 students who took part in both translation tests. All the subjects were students of the Linguistics 2 course. The rationale behind selecting these students was to include those students who had, at least, passed their special course, Linguistic 1, and therefore had been familiar with the affixation and the process of word-building; in this way, reliable results as well as more meaningful conclusions would be obtained.

\section{B. Data Collection Instruments}

The necessary data in this study were collected through two translation tests and an interview which are described in the following sections.

\section{Translation Tests}

Participants were given two vocabulary tests, one week apart. Test 1 asked the participants to translate 32 words, included 16 derived words such as assignment, exporter, complexity, and indication and 16 headwords such as, achieve, lecture, secure and violate representing 32 different families. In test 2 the head words and derived words were reversed, it means that head words were changed to derived words and vice versa; 16 head words such as assign, export, complex indicate, and assess and 16 derived words such as achievement, lecturer, security and violation. For example, if in the first week assignment, in the second assign. The translation from English (L2) to Persian (L1) was used to assess the students' receptive knowledge (see Appendix A).

For the test, the word families were chosen from Academic Word List (AWL). More than $82 \%$ of the words in the AWL "are of Greek and Latin origin" (Coxhead, 2000, pp. 228-229), making the list a prime source for words requiring morphological analysis.

Regarding the affixes used in the test, Bauer and Nation (1993) graded affixes for purposes of teaching and learning into seven levels, based on various criteria which may roughly be summarized according to ease of learning and frequency of occurrence. At level 1 all word types were treated as separate. At level 2 one finds inflectional affixes like -ing and -s, which are very common (Nation, 2001, p. 265) and (being strictly rule-based) presumed learnable. At level 3 , with the introduction of derivational affixes, one finds (among others) the affixes -able, -less, -er and -ness. At level 4 -tion, -ity, -al, -ful and -ment can be found. Levels 5 to 7 comprise the levels of suffixes that are regular but 
infrequent, or frequent but irregular and classical roots and suffixes, and are not chosen because the rules of building words may be too complex for the students. From these supposedly easier and demonstrably frequent suffixes the researchers chose -tion, -er, -ity and -ment for investigation; if the learners were word-builders, it is relatively likely that these suffixes will be in their repertoire.

\section{Interview}

An interview was run for two purposes: first, to check the reliability of the students' responses in the two translation tests, and second, to find more information about the students' use of word-building strategy to recognize derived words. The interview was conducted both in English and Persian and tape-recorded by the researchers, and then the responses in the interview were transcribed (see Appendix B).

\section{PROCEDURE}

The students were tested through two translation tests a week apart, so that the students' responses in the first test did not affect the second test. The researchers gave the first test to the students in the first week without informing them about the second test in the following week. The instruction of the test was given in Persian by the researchers in order to ensure that the students understood how to carry out the test. Each test had a list of headwords and derived words, so students had to translate 32 words from L2 to L1 within 14 minutes.

\section{DATA ANALYSIS}

To analyze, both qualitatively and quantitatively, the data obtained through administering the translation tests and the interview, the followings were done:

1. Cronbach Alpha was used for estimating the reliability between the two translation tests,

2. descriptive statistics were calculated for the tests to see the minimum, maximum, mean, and standard deviation of the tests,

3. inferential statistics, that is, paired-samples t-test, was used to compare the results of the two tests.

The responses in the interview may give information about how the subjects recognized the tested words

\section{RESULTS}

The two translation tests were estimated for the reliability through Cronbach's Alpha Cronbach's Alpha; the values of two tests were 0.754 and 0.785 respectively, which indicated high reliability. The results of the two translation tests were scored as 1 for correct responses and 0 for non-responses and incorrect responses. The total scores of tests 1 and 2 were compared using paired-sample $t$-test in order to see if they were different. The $\mathrm{t}$-value showed that there was not a significant difference between two tests $(t=.789, \mathrm{p}>.001)$. The figures indicate no significant difference between the mean of test $2($ Mean $=14.20, \mathrm{SD}=5.162)$ and test $1($ Mean $=14.03, \mathrm{SD}=4.620)$. This means that students did not translate words in test 2 better than test 1 or vice versa.

Table 1 gives the participants' percentage knowledge of each noun suffix

TABLE1.

Percentage of Students' KnOWledge of Each Noun SufFiX

\begin{tabular}{lllllllll}
\hline \multicolumn{1}{l}{ PERCENTAGE OF STUDENTS' KNOWLEDGE OF EACH NOUN SUFFIX } \\
\hline Level & -tion & $\%$ & -er & $\%$ & -ment & $\%$ & -ity & $\%$ \\
\hline 1. Both & 78 & 32.5 & 62 & 25.83 & 48 & 20 & 67 & 27.92 \\
\hline 2. head word (HW) only & 55 & 22.196 & 13 & 5.42 & 24 & 10 & 51 & 21.25 \\
\hline 3. derived word (DW) only & 51 & 21.25 & 71 & 29.58 & 53 & 22.08 & 27 & 11.25 \\
\hline 4. None & 56 & 23.33 & 94 & 39.167 & 115 & 47.92 & 95 & 39.58 \\
\hline Total & 240 & 100 & 240 & 100 & 240 & 100 & 240 & 100 \\
\hline
\end{tabular}

Recalling that each participant translated 8 word pairs (e.g., equip/equipment) for each suffix; there were thus 240 ( 8 $\times 30)$ responses for each suffix type. The above table shows the percentage of responses at each level-level 1 showing the knowledge of both forms and thus the possibility of word-building to take place; level 2 and 3 showing the knowledge of either one or the other, but not both, of the forms, indicating an absence of word-building; and level 4 showing the knowledge of neither form, and thus the impossibility of word-building.

\section{DISCUSSION}

The results are discussed in the following parts with regard to the research question "do students recognize derived forms directly or through a process of word- building?" The results contradict the assumption that knowledge of headwords implies knowledge of word families, at least with students from Persian L1 backgrounds.

Table 2 below compares the number of level 1 responses with the combined total of level 2 and 3 responses, for this group of participants. Remember that condition 1 shows that participants might be word-builder, conditions 2 and 3 that they are not. In the majority of cases participants demonstrated word-building skills far less often than the opposite. 
TABLE 2.

STUDENTS' LEVEL 1 RESPONSES VS. LEVEL2/3 RESPONSES

\begin{tabular}{|l|l|l|}
\hline Affixes & Level 1 & Level 1+2 \\
\hline -tion & 32.5 & 43.446 \\
\hline -er & 25.83 & 35 \\
\hline -ment & 20 & 32.08 \\
\hline -ity & 27.92 & 32.5 \\
\hline
\end{tabular}

Considering the percentages of levels 2 and 3, which are much higher than level 1, it is shown that in most cases this group of students did not understand these suffixes. Instead, they understood individual words (not word families).

However, from examining each word family (from two translation tests) there were six word families (pairs) that students' responses in level 1 were greater than levels $2+3$. They were 'select/selection', 'define/definition', 'design/designer', 'publish/publisher', 'similar/similarity', and 'establish/ establishment'.

The percentage of level 1 for 'select/selection' (70\%) is greater than the sum of levels 2 and $3(26.6 \%)$, and level 1 for 'define/definition' (53.33) is greater than the sum of levels 2 and $3(30.04 \%)$.

The percentage of level 1 of 'design/designer' and 'publish' and 'publisher' $(53.33 \%)$ is greater than the sum of levels 2 and $3(36.67 \%)$.

The percentage of level 1 of 'similar/similarity' (56.67\%) is greater than the sum of levels 2 and $3(36.73 \%)$.

The percentage of level 1 of 'establish/establishment' (23.33\%) is greater than the sum of levels 2 and $3(10.07 \%)$.

These twelve words- select/selection', 'define/definition', 'design/designer', 'publish/publisher', 'similar/similarity', and 'establish/ establishment'- might have affected the total scores of the suffixes- -tion, -er, -ity, and -ment- to reach $32.5 \%, 25.83 \%, 23.75 \%$, and $13.75 \%$ respectively.

After examining each word family (pair), the researchers also checked each participant's answer sheets to see whether any participant tended to use word-building strategy or not. They also checked each suffix type and counted how many word families (pairs) that student answered/translated. Since there is no previous study to refer to for the purposes of discussion, students were considered to be a word-builder if they could answer headword and its derived word for at least half of all word families in the same suffix. Thus, a highly tentative assumption was made that students who got $50 \%$ of all words (or at least 4 out of 8 word families or pairs) were word-builders.

Based on the examination, there were only 12 participants (out of 30) who could be considered word-builders; students $1,8,10,13,19,20$ were the seven students who may have used word-building strategy to recognize the meaning of derivative form -tion; six other students- students 1, 4, 8, 14, 19 and 20- may have used word-building strategy to recognize the meaning of derivative form -er; five other students- students 1, 8, 19, 20, and 21- may have used word-building strategy to recognize the meaning of derivative form -ment; and seven other students- students 1,8 , $10,21,22,23$ and 24 may have used word-building strategy to recognize the meaning of derivative form -ity. This information is tabulated in Table 3 below.

TABLE 3.

PARTICIPANTS WHO COULD BE CONSIDERED WORD-BUILDERS

\begin{tabular}{|c|c|c|c|c|}
\hline Name & Suffix -tion & Suffix -er & Suffix -ment & Suffix -ity \\
\hline Student 1 & $\begin{array}{l}\text { predict, select, define, and } \\
\text { estimate }\end{array}$ & $\begin{array}{l}\text { export, consume, } \\
\text { publish, publisher }\end{array}$ & $\begin{array}{l}\text { invest, require, } \\
\text { establish, adjust, equip }\end{array}$ & $\begin{array}{l}\text { complex, secure, capable, } \\
\text { similar }\end{array}$ \\
\hline Student 4 & & $\begin{array}{l}\text { publish, design, } \\
\text { research, consume }\end{array}$ & & \\
\hline Student 8 & $\begin{array}{l}\text { select, predict, indicate, and } \\
\text { construct. }\end{array}$ & $\begin{array}{l}\text { design, publish, export, } \\
\text { consume }\end{array}$ & $\begin{array}{l}\text { adjust, establish, } \\
\text { require, achieve, invest, } \\
\text { equip }\end{array}$ & $\begin{array}{l}\text { complex, secure, similar, } \\
\text { capable }\end{array}$ \\
\hline $\begin{array}{l}\text { Student } \\
10\end{array}$ & $\begin{array}{l}\text { predict, estimate, select, and } \\
\text { define }\end{array}$ & & & $\begin{array}{l}\text { complex, valid, similar, } \\
\text { flexible }\end{array}$ \\
\hline $\begin{array}{l}\text { Student } \\
13\end{array}$ & select, create, predict, estimate & & & \\
\hline $\begin{array}{l}\text { Student } \\
14\end{array}$ & & $\begin{array}{l}\text { design, publish, } \\
\text { research, consume }\end{array}$ & & \\
\hline $\begin{array}{l}\text { Student } \\
17\end{array}$ & & $\begin{array}{l}\text { publish, design, } \\
\text { consume, export }\end{array}$ & & \\
\hline $\begin{array}{l}\text { Student } \\
19\end{array}$ & $\begin{array}{l}\text { select, predict, estimate, and } \\
\text { construct }\end{array}$ & $\begin{array}{l}\text { research, export, } \\
\text { design, publish }\end{array}$ & $\begin{array}{l}\text { invest, adjust, establish, } \\
\text { require }\end{array}$ & \\
\hline $\begin{array}{l}\text { Student } \\
20\end{array}$ & $\begin{array}{l}\text { define, construct, predict, } \\
\text { estimate, select, create }\end{array}$ & $\begin{array}{l}\text { challenge, publish, } \\
\text { design, export, occupy, } \\
\text { consume }\end{array}$ & $\begin{array}{l}\text { achieve, invest, assign, } \\
\text { adjust, establish, require }\end{array}$ & $\begin{array}{l}\text { similar, flexible, capable, } \\
\text { valid, secure, complex, } \\
\text { intense }\end{array}$ \\
\hline $\begin{array}{l}\text { Student } \\
21\end{array}$ & & $\begin{array}{l}\text { consume, export, } \\
\text { challenge, publish }\end{array}$ & $\begin{array}{l}\text { achieve, equip, adjust, } \\
\text { establish }\end{array}$ & $\begin{array}{l}\text { capability, similar, flexible, } \\
\text { secure }\end{array}$ \\
\hline $\begin{array}{l}\text { Student } \\
22\end{array}$ & & & & $\begin{array}{l}\text { complex, similar, capable, } \\
\text { valid }\end{array}$ \\
\hline $\begin{array}{l}\text { Student } \\
24\end{array}$ & & & & $\begin{array}{l}\text { secure, complex, capable, } \\
\text { valid, similar }\end{array}$ \\
\hline
\end{tabular}


The results show that the students have some word-building knowledge, but most of them use direct method and not word-building strategy to find the meaning of the tested words. Therefore, the null hypothesis of the research stating that "there is no difference between the direct and word-building process of derived nouns recognition by Iranian students" can be rejected.

However, the result of this study is consistent with the previous study by Schmitt and Zimmerman's (2002, p. 158), who assumed that knowing some words in a word family did not "imply productive knowledge of all (or even most) of the other word forms", and Paribakht (2004), who studied the role of morphology in second language lexical processing which, later, led to vocabulary acquisition. She aimed to find strategies learners used to construct the meaning of unknown words in their reading. Paribakht's (2004) results showed that students saw parts in a word-both inflection and derivation, they could not give the meaning or re-express the meaning of the whole word from word parts they saw. This showed that, in fact, students did not have knowledge of word morphology. They could not make use of parts in a word. The results only showed that students might have some background about word morphology (or in the present study called word-building knowledge). This showed that word-building did not lead to vocabulary learning and did not promote comprehension in reading.

In term of learning, the question arises why -er and -tion showed above half, but it is not true with the suffixes -ity and -ment. The evidence in this study is insufficient for any firm conclusion, but a tentative explanation may be offered. Following Bybee (Bybee, 1995, 2006) it can be assumed, for the sake of this argument, that input frequency is a significant factor in L2 as in L1 acquisition. Bybee (2005, p. 6) suggests that "words with derivational affixes become less transparently related to their base forms as they become more frequent". The derived words which are accessed more by the students have a chance to be stored in brain as unanalyzed units. The case does not happen only to learners who study English as a second or foreign language, but the native speaker also (Nation, 2001). Native speaker children do not pay attention to the history of word or the derivation but they are concerned with the obvious meaning of word. Moreover, the frequency of use is different in each student because they encountered different words in their lives.

Besides the frequency of use, there are other reasons to support that some students did not very well succeed in using this strategy. First, it is possible that some students become less accurate in using word-building strategy because they do not use the strategy in their language learning. Cohen (1987) mentions that when language learners are away from using a strategy, they tend to become less accurate in using the strategy as well.

Another reason is that some students misunderstood what suffixes do. Although the students recognized that suffixes were used in the tests to make noun, they did not relate the meaning of the nouns to the meaning of the headwords; knowing the meaning of assignment, however, does not mean knowing assign and suffix -ment, but it is because suffix -ment makes a noun and the student tried to guess which Persian word is likely to be the correct meaning of Assignment. It did not mean that she/he had to re-express the meaning from assign + ment (the case of Student)].

This result is against the results from Mochizuki and Aizawa's (2000) study. It argues that knowing word class does not indicate students' affix knowledge. Although the words in this study were high-frequency words from the AWL, they were not very frequent to some students. Students might have encountered some other words which might not exist in the AWL. In turn, students had less exposure to academic textbooks. Of course, it is possible that they had some problems in their academic reading since they had little knowledge of academic words and about the below-average word-building knowledge. For this reason, the derived words that some students answered in this study might not be because of word-building knowledge but the recognition of as unanalyzed word which students encounter often in their daily life. This result also refers to the students' response in the interview. It argues that the students convinced the researcher that they had word-building knowledge. In fact, from both translation tests and the interview, some could answer only one headword or derived word. Although the interviewed students tried to show positive thinking towards word-building, they did not show evidence that the word parts are useful to them. Students answered some of the derived words although the words were semantically transparent (the meaning of word was clear from the parts).

\section{CONCLUSION}

The process of dividing up words to make easy the understanding or learning of a text is a strategy which is based on a complicated analysis derived from the knowledge of classical or Latinate language. This way of dealing with the comprehension of a text seems to provide a suitable shortcut to vocabulary learning. However the results obtained from the present study suggested otherwise. This contradiction may be because the uninitiated morphological analysis involves using a whole system of unfamiliar rules. This process has connotations for both word family usage and acquisition or teaching of complex words.

One of the factors which appears to influence students' word recognition might be the frequency of the words students usually find in their daily lives which are not only headwords but word derivations as well. The participants in this study recognized frequent words and some other words associating these frequent words in inferring other words with the same stem. 


\begin{tabular}{|l|l|l|l|}
\hline Test 1 & Test 1 & Test 2 & Test 2 \\
\hline Head words & Derived words & Head words & Derived words \\
\hline Design & Challenger & Challenge & Designer \\
Lecture & Exporter & Export & Lecturer \\
Publish & Occupier & Occupy & Publisher \\
Consume & Researcher & Research & Consumer \\
Equip & Assignment & Assign & Equipment \\
Require & Achievement & Achieve & Requirement \\
Invest & Assessment & Assess & Investment \\
Establish & Adjustment & Adjust & Establishment \\
Violate & Prediction & Predict & Violation \\
Estimate & Creation & Create & Estimation \\
Select & Construction & Construct & Selection \\
Define & Indication & Indicate & Definition \\
Secure & Complexity & Complex & Security \\
Similar & Intensity & Intense & Similarity \\
Capable & Diversity & Diverse & Capability \\
Flexible & Validity & Valid & Flexibility \\
& & & \\
\hline
\end{tabular}

\section{APPENDIX B}

\section{The Interview Questions for Iranian Learners}

1. After reading word carefully, can you please give the meaning of words in Persian again?

2. Are there any parts in the word that help you to recognize its meaning?

3. Do you think the suffixes-ment,-- tion,--ity ,-er have any meaning? If yes, what are they? Do you know how to use such suffixes? (Words which will be asked in the interview questions 1-3 are different in each subject depend on what they can answer in the translation tests.)

4. Please rank vocabulary strategies that you use (put 1 for strategy which you usually use, then 2,3 up to 7 for the strategy that you rarely use).

vocabulary Strategies

Rank

word list

synonym \& antonym

mnemonic technique

(sound similarity to Persian)

mnemonic (pictures)

word parts

context clues

others

5. Have you looked up the meaning of words in the first test in the dictionary? If yes, how many of them?

\section{ACKNOWLEDGEMENTS}

Once more, we like to express our deepest gratitude to Dr. Omid Tabatabai of the English department at Najafabad Islamic Azad University for guiding us with his wisdom, expertise, and encouragement and Dr. Jeremy Ward for his help through emails

\section{REFERENCES}

[1] Bauer, L., \& Nation, I. S. P. (1993). Word families. International Journal of Lexicography, 6, 253-279.

[2] Bybee, J. (1995). Regular morphology and the lexicon. Language and Cognitive Processes 10, 425-455.

[3] Bybee, J. (2005). From usage to grammar: the mind's responses to repetition. Retrieved January, 25, 2007, from http://www.unm.edu/ jbybee/Bybee\% 20plenary.pdf.

[4] Bybee, J. (2006). From usage to grammar: the mind's response to repetition. Language 82(4), 711-733.

[5] Carter, R. (1998). Vocabulary: Applied linguistic perspective. London: Routledge.

[6] Cohen, A. D. (1987). The use of verbal and imagery mnemonics in second language vocabulary learning. In A. D. Cohen (Ed.), Strategies in learning and using a second language (p. 24). Malaysia: Longman.

[7] Coxhead, A. (2000). A new academic word list. TESOL Quarterly, 34(2), 213-238.

[8] Laufer, B. (1989). What percentage of text-lexis is essential for comprehension? In P. Nation, \& R. Waring. (Eds), Vocabulary size, test coverage and word lists. from http://www1.harenet.ne.jp/ waring/papers/cup. html

[9] Levine, A., \& Reves, T. (1998). Interplay between reading tasks, reader variables and unknown word processing. In A. Mirhassani \&A. Toosi(Eds), The impact of word-formation knowledge on reading comprehension. IRAL Journal, 38, $301-311$.

[10] Wilkins, D. (1972). Linguistics in Language Teaching. London: Edward Arnold. 
[11] Meara, P. (1996). The dimensions of lexical competence. In G. Brown, K. Malmkjare,\& J. Williams (Eds), Performance \& competence in second language acquisition (pp. 35-53). Great Britain: Cambridge University Press.

[12] Mochizuki, M., \& Aizawa, K. (2000). An affix acquisition order for EFL learners: an exploratory study. System, 28, $291-304$.

[13] Mori, Y., \& Nagy, W. (1999). Integration of information from context and word elements in interpreting novel kanji compounds. Reading Research Quarterly, 34, 80-104. Publishers.

[14] Nation, I. S. P. (1990). Teaching and Learning Vocabulary. Massachusetts: Newbury House.

[15] Nation, I. S. P. (2001). Learning Vocabulary in Another Language. Cambridge: Cambridge University Press.

[16] Nation, I.S.P. (2005). Teaching and Learning Vocabulary. In Hinkel, E. (eds). Handbook of research in second language teaching and learning (pp. 581-595). Lawrence Erlbaum Associates: London.

[17] National Reading Panel. (2000). Teaching children to read: An evidence-based assessment of scientific research literature on reading and its implication for reading instruction: Report of subgroups. Washington, D.C: National Institute of Child Health and Human Development.

[18] Nattinger, J. (1988). Some current trends in vocabulary teaching. In R. Carter \& M. McCarthy (Eds), Vocabulary and language teaching. London: Longman.

[19] Paribakht, T. S. (2004). The role of grammar in second language lexical processing. RELC Journal, 35(2), 149-160.

[20] Richards, J. C. (1976). The role of vocabulary teaching. TESOL Quarterly, 10, 77-89.

[21] Schmitt, N. (2000). Vocabulary in Language Teaching. Cambridge: Cambridge University Press.

[22] Schmitt, N. \& McCarthy, M. (1997). Vocabulary: Description, acquisition, and pedagogy. Cambridge: Cambridge University Press.

[23] Schmitt, N., \& Meara, P. (1997). Researching vocabulary through a word knowledge framework. SSLA, 19(1), 17-36.

[24] Schmitt, N., \& Zimmerman, C. B. (2002). Derivative word forms: what do learners know? TESOL Quarterly, 36/ 2, $145-171$.

Mitra Amiri is a second year M.A candidate of English teaching at Islamic Azad university of Najafabad Branch, Isfahan, Iran year 2010 and she received her B.A degree in English translation field from Islamic Azad university of Shahreza Branch, Isfahan, Iran in 2006. Her main interests are general linguistic and discourse analysis.

Miss. Amiri is now working as a Teaching Assistant at Islamic Azad university of Semirom Branch, Isfahan, Iran.

Akbar Hesabi has PhD in applied linguistic and works as Lecturer and one of Teaching Assistance at English Department, University of Isfahan, Iran. His areas of interest include Linguistics, Neurolinguistics, Computational Linguistics and Machine Translation. He has published several articles in these areas.

Abbass Eslami Rasekh has a PhD in applied linguistics and works as an assistant professor at Isfahan University, Iran. He is teaching graduate courses like ESP (English for Specific Purposes), sociolinguistics, and discourse analysis at both master`s and doctoral levels. 